\title{
インドネシアKahayan川の水位変動要因を 踏まえた水位予測に関する研究 \\ RESEARCH ON WATER LEVEL FORECASTING BASED ON FACTORS AFFECTING WATER LEVEL VARIATION FOR THE KAHAYAN RIVER IN INDONESIA
}

\author{
工藤俊 ${ }^{1}$ ・ 中津川誠 ${ }^{2}$ \\ Shun KUDO and Makoto NAKATSUGAWA \\ 1学生会員 室蘭工業大学大学院 工学研究科（干050-8585 室蘭市水元町27-1） \\ ${ }^{2}$ 正会員 博士 (工学) 室蘭工業大学大学院 工学研究科 准教授（空050-8585 室蘭市水元町27-1）
}

\begin{abstract}
This study aims to clarify the factors affecting water level variations in the Kahayan River in Indonesia, and aims to forecast the water level of that river. In recent years, peat land has been drying as a result of agricultural development, and such drying has increased the frequency of large-scale wildfires.

To analyze the factors affecting water level variation, we examined the relationships between global weather phenomena, rainfall in the study area and water levels of the river. It was found that rainfall was scant and the water level was low during El Niño events. In addition, it was found to be possible to forecast water level fluctuations with a one-month lead time by using the Nearest-Neighbor Method. The results promise to be useful for controlling the hydrological conditions in peat land restoration in the future.
\end{abstract}

Key Words : Kahayan River, peat fires, El Niño event, water level forecasting, Nearest-Neighbor Method

\section{1. はじめに}

インドネシアの熱帯泥炭には多量の炭素が蓄積されて いるが，近年の農地開発の影響で地下水位が低下するこ となどが原因とみられる泥炭地の乾燥化が起き，大規模 な火災を引き起こしている，それにより中部カリマンタ ンだけでも毎年，日本の年間排出量に相当するほどの膨 大な量の二酸化炭素が放出されており ${ }^{1)}$ ，国際的な課題 となっている.

このため，泥炭火災を防ぐために地下水位を正常な状 態にコントロールし泥炭地の乾燥を抑制することが求め られており，そのためには現地の水文環境を理解し，さ らにその変動を把握した上で対策を講じる必要がある.

これまで, 中部カリマンタンのKahayan川流域と, 隣接 するSebangau川流域を対象に地下水位変動と泥炭火災の 関係を分析した佐藤ら ${ }^{2)}$ の研究や早坂 ら ${ }^{3)}$ の研究，カリマ ンタンの泥炭地における蒸発散量と流出量の推定を行っ た三宅ら ${ }^{4)}$ の研究など，泥炭地の水文環境に着目した研 究事例があるが，地下水や表流水の変動要因そのものを 詳細に分析した研究は少ない.

そこで本研究では，Kahayan川流域を対象に地下水位
との関係が深い河川水位の変動要因について, その中で も泥炭火災の危険が特に高い乾季に着目した分析を行っ た. 具体的には，まず初めにグローバルな気象現象をも とに乾季の流域雨量を左右する要因の分析を行い，その 上で気象現象と河川水位の比較・検証を特に低水時に着 目して行った．また，変動要因が解明された上でさらに， 低水時を予測できれば水位低下を事前に把握でき，水位 低下を防ぐための水路での堰上げなどといった流域管理 に役立てられると考え，水位予測を試みた。なお， Kahayan川の水位予測を試みる上では, 水文データの少 ない流域においても, 確保しうる水文データの現在と過 去のデータがあれば予測が行えるNearest-Neighbor法（以 下，NNM）を採用し，月単位での水位予測を試みた。

\section{Kahayan 川の概要}

Kahayan川はインドネシア・中部カリマンタンに位置 し，流域面積については中央カリマンタン州政府

(Dinas PU Propinsi Kalimantan Tengah) によると, 19,917 $\mathrm{km}^{2}$ とされている.また下流では平坦な土地が広 がり，内陸部まで潮汐の影響を大きく受けることが知ら 


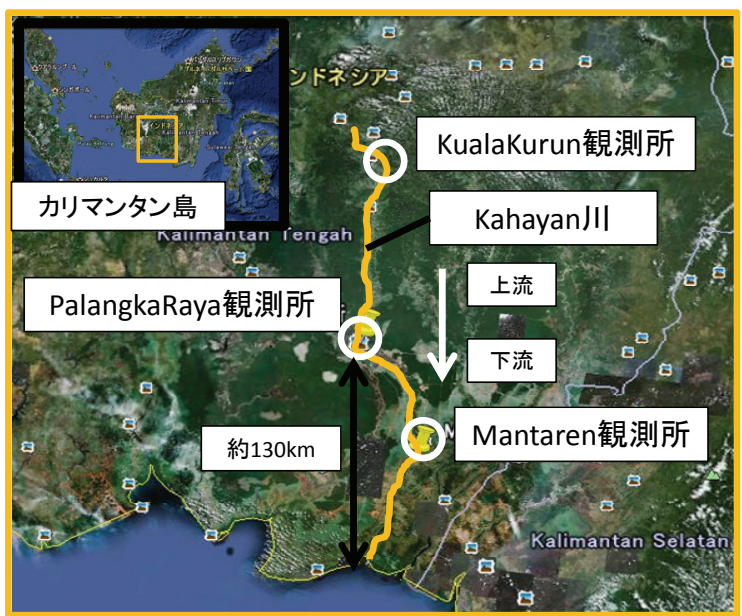

図-1 Kahayan川周辺図

れており，上流になるにつれて川の勾配が大きくなると いう特徴を有する. 本研究では周囲に豊かな泥炭地が広 がるPalangkaRaya観測所（図-1参照）で観測された水位 を用いて水位の変動要因分析と水位予測を行う。

\section{3. 雨量 · 水位の変動要因の分析}

インドネシアの雨量を左右するグローバルな気象現象 として, El Niño event・La Niña event・Indian Ocean Dipole mode（以下, IOD）を考え，それが具体的に Kahayan川流域の雨量, 水位にどのように影響している かを検証する，それぞれの現象は海域の東風の強さによ る海水面温度の東西のコントラストの強さによるもので ある. 概要を表-1に示す.

\section{（1）乾季積算雨量と気象現象 - 大規模泥炭火災の関係}

水位の変動要因の分析に先立ち, より気象現象と直接 的な関係があると考えられるKahayan川流域平均雨量を 利用した分析を行う．使用データについては，図-1に示 したPalangkaRaya観測所，KualaKurun観測所，Mantaren 観測所の3つの観測所の1990年〜2009年において観測さ れた日雨量を用いて月雨量を算出し使用した。 この際， 欠測があるため 1 ケ間の日数の 8 割以上の日数で観測さ れた月の日平均雨量を算出し，それに1ヶ月の日数を乗 じることにより月雨量を算出している．観測日数が 8 割 に満たない月は欠測とした．その上で，3つの観測所に おける月雨量を算術平均したものを流域平均雨量とした

分析には，1章において述べた通り乾季に着目するた めに乾季積算雨量を用いる. ここで，国際機関日本アセ アンセンター5)によるとカリマンタンの乾季は7月～9月 であるため，乾季積算雨量とは7月～9月の3 月積算雨 量のことを表す. 乾季積算雨量とそれぞれの気象現象・ 大規模泥炭火災の発生期間22,3, (,6,7,8,8,9) を比較・分析し，分 析結果を図-2に示した。 なお，7月～9月の3ヶ月間で1ヶ 月間でも欠測のあるものは，乾季積算雨量も欠測として
表-1 気象現象の概要

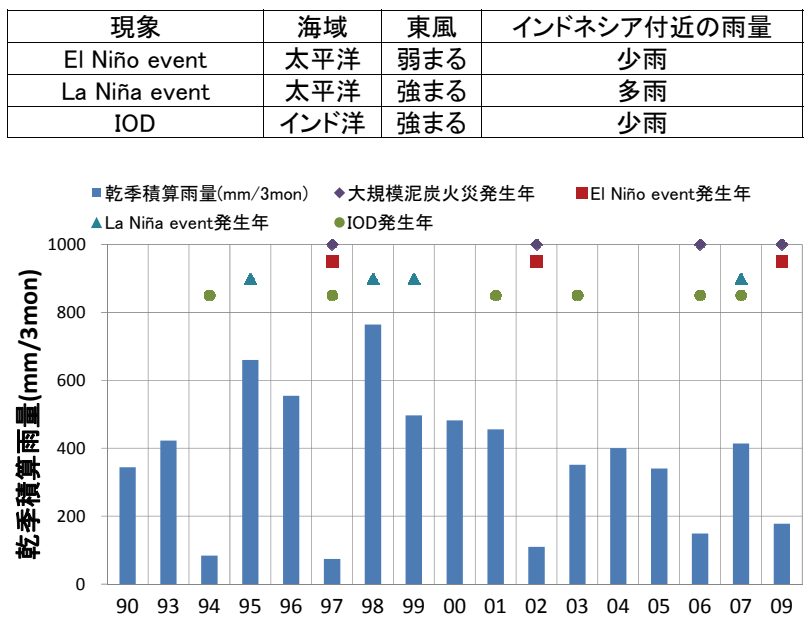

図-2 乾季積算雨量の分析 (91年, 92年, 08年は欠測)

いる. また，乾季積算雨量と年積算雨量の関係について は，図-2に示した17年間の年平均の乾季積算雨量が 370(mm/3mon), 年積算雨量が3054(mm/year)（ただし, 93年は1月，2月が欠測であったため平均值算出時からは 除外した）となっている.

図-2に着目寸ると，El Niño eventが発生している97年, 02年，09年にはいずれの年も少雨となっており，このこ とからEl Niño event とKahayan川流域の乾季積算雨量には 密接な関係にあることが十分に読み取れる。また, IOD が発生している年について，94年，97年，06年について みると少雨となっているが，01年，03年，07年について はIODが発生しているにも関わらず, 少雨ではないこと がわかる.このことについて考察すると，07年について はLa Niña eventが同時に発生しており，このことが少雨 とならなかった原因であると考えられる。しかしながら， 01年，03年についてはLa Niña eventが発生しておらず, 少雨とならない原因はさらに精查する必要がある.

なお，大規模泥炭火災が発生した97年，02年，06年， 09年に着目してもいずれの年も少雨であることがわかる. これらの年の気象現象と比較すると02年，09年はEl Niño eventが発生し，06年はIODが発生し，97年は両者が発生 していることがわかる.このことから，El Niño eventと IODの両者を考慮することの必要性が示唆されている.

次に, El Niño eventとIODが同時に起き, 大規模泥炭 火災が発生した97年の乾季積算雨量図と90年〜09年の年 平均の乾季積算雨量図を確認する. 雨量データは世界気 象機関らのプロジェクトである全球降水気候計画(Global Precipitation Climatology Project)（以下, GPCP) より, $0.5^{\circ}$ グリッドデータ10)使用し，7月～9月の3ヶ月間の乾 季積算雨量図を図-3に示した.

図-3の両者を比較すると，丸で囲われたKahayan川流 域付近での雨量の差が明確であり, 気象現象による乾季 の少雨が流域全体にわたっていることがわかる. 


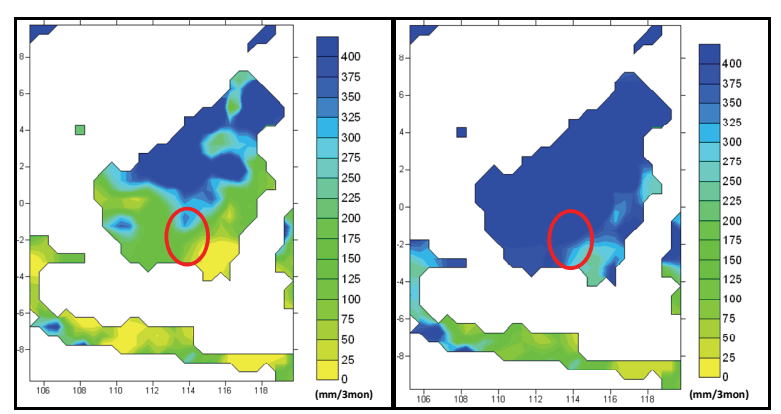

図-3 乾季積算雨量図（左 : 97 年，右 : 90 年 09年平均)

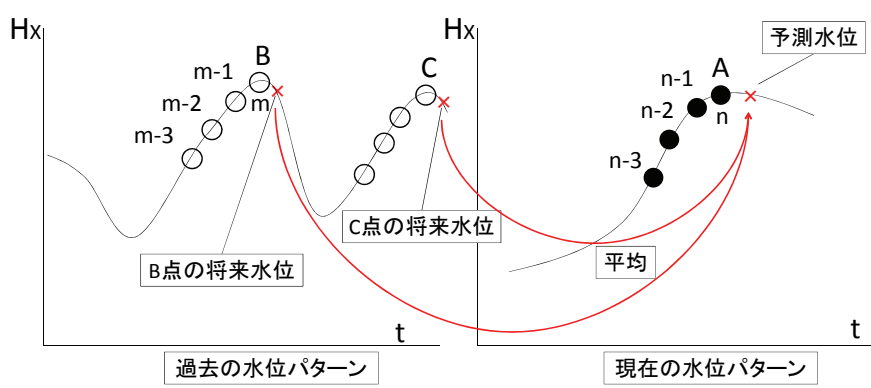

図-5 NNMイメージ図

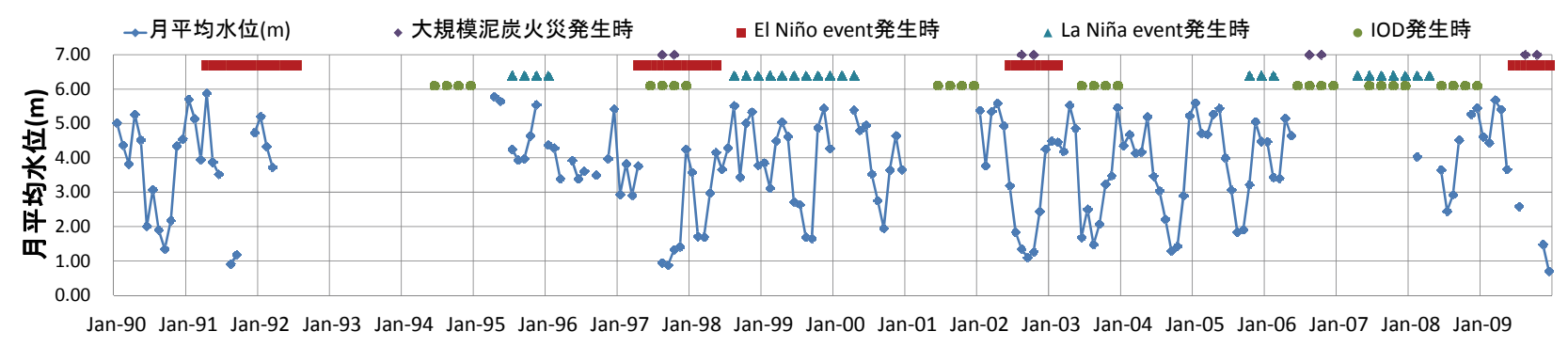

図-4 水位の分析（水位が示されていない箇所は欠測）

\section{（2）水位と気象現象 - 大規模泥炭火災の関係}

PalangkaRaya観測所において観測された水位について 分析を行う. 使用するデータは1990年〜2009年に観測さ れた日水位データを月平均したものを使用する。 この際, 1 ケ月間の日数の 8 割以上の日数で観測された月のみの平 均を算出し, 観測日数が8割に満たない月は欠測とした. 分析結果を図-4に示す。ここで，水位は統一的な基準面 からの高さではなく, 観測所ごとの基準面からの高さで ある、なお，それぞれのイベント発生月としては，El Niño event, La Niña eventについては気象庁のの定義を使 用し，IODについては一般的に5〜6月に発生し10月に最 盛期を迎え，12月には減衰する9 ことから，発生したと される年の5月～12月とした。 大規模泥炭火災について は，火災が生じや寸いのは乾季の末期の8月〜10月2)であ ることから，発生年の8月〜10月とした.

図-4に着目すると，水位が1m前後まで低下している 91年，97年，02年，09年ではいずれもEl Niño eventが発 生しており，乾季積算雨量を用いた分析と同様な結果が 得られることがわかる．さらに，97年，02年，09年につ いては大規模泥炭火災が発生しており，さらなる検証が 必要ではあるが，水位 $1 \mathrm{~m}$ 前後というのが大規模泥炭火 災発生の指標として使える可能性が示唆されている．ま た，03年，08年においてはIODが発生しているにも関わ らず水位が低いとはいえない。08年については，La Niña eventの末期であるために水位が低下しなかったこ とが考えられ、03年については乾季積算雨量を用いた分 析と同様に，さらに精査していく必要があるといえる.

以上より, El Niño eventについては雨量, 水位との強 い相関が示されたといえる，IODについては，発生期間 中の水位の観測がそしく水位との十分な関係は得られて いないが，水位と深い関係にある雨量との関係は得られ
ており水位の変動要因という意味合いではIODも一つの 要因となっていることが検証されたといえる.

\section{4. 水位予測}

前章までで水位の変動要因が検証されたが本章ではこ れを踏まえて, 特にEl Niño eventによって左右される低 水時を予測することを試みる，低水時を事前に予測する ことで, 河川・水路の堰上げを行い泥炭地の乾燥を事前 に抑制することなどに役立てたいが，現地での実用性を 考えると日単位での堰のオペレーションは難しく, 月単 位での予測の方が現地での堰の管理に役立つと考え，本 研究では月単位での予測を試みた，また，水位予測をす る際は雨量〜流量〜水位といった変換過程をたどる方法 が一般的であるが，Kahayan川では定期的な流量観測が 行われておらず流量を介した予測が困難であるため，本 研究では水文データがそしい流域においても予測が行え るNNMを適用した。 なお，予測対象は周囲に泥炭地や 農地，市街地が広がるPalangkaRaya観測所の水位とする.

\section{(1) NNMの概要}

NNMとは一種のパターンマッチングのような手法で あり, 現在の水位パターンと類似した過去の水位パター ンから, 将来の水位を予測するものである.

具体的には図-5のように考え，X地点のA時の将来の 水位を予測することを考えると，まず，A時から遡った 連続する水位パターン（黒丸で示す）と類似な水位パ ターンを過去の水位パターンから探す. B時から遡った 連続水位（白丸で示寸）が最も類似なパターンで， $\mathrm{C}$ 時 から遡った連続水位（同様に白丸で示す）が2番目に類 


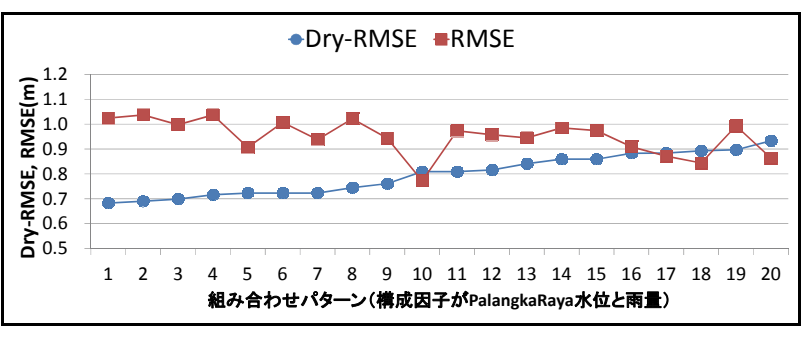

図-6 Dry-RMSEとRMSEの推移（1ヶ月先予測, 構成因子が PalangkaRaya水位と雨量)

似なパターンだとすると， $\mathrm{B}$ 時の将来水位と $\mathrm{C}$ 時の将来 水位の平均をA時の予測水位する.

ここで，連続する水位の個数（以下M） と過去からの 事例の抽出数（以下K）は様々な組み合わせが考えられ, 図-5はM=4，K=2の例である。.また，他の水文データの 現在と過去のパターンの比較も合わせて利用することも でき，これを構成因子という。

なお，類似した過去の水位パターンの抽出には，次式 に示すユークリッド距離が小さくなるものを抽出する. ユークリッド距離=

$$
\sqrt{\left\{H_{X}(n)-H_{X}(m)\right\}^{2}+\left\{H_{X}(n-1)-H_{X}(m-1)\right\}^{2}+\cdots}
$$

ここで, $H_{X}(n)$ はX地点の現在水位, $H_{X}(m)$ はX地点の過 去水位，n-1，m-1はそれぞれ1時点前データである.

NNMを用いた水文資料の予測については，洪水時の 水位予測や感潮河川の水位予測へ適用した満倉ら ${ }^{11), 12)}$, 過去のデータベースの期間の長さや流域内雨量観測点数 が予測精度に及ぼす影響を詳細に検討し，流出予測を 行った藤原ら ${ }^{13)}$ ，Kahayan川の水位の日単位予測を試み た三野ら ${ }^{14)}$ の研究事例があるが，低水位予測に主眼を置 いた研究は稀であるといえる.

\section{（2）予測対象期間とデータベース期間}

予測対象期間は，近年において比較的連続して観測が 行われている2002年〜2005年とし，データベース期間は， PalangkaRaya観測所において水位観測が始まった1980年 〜2000年とした. 使用するデータは全て月データである.

\section{（3） 構成因子，M，Kの選定}

まず，構成因子にPalangkaRaya観測所のみを用いる場 合と, 流域平均雨量（以下，雨量とは全て流域平均雨量 を表す）を追加する場合の2通りを考える。この時， PalangkaRaya水位のM（以下, MWp）, 雨量のM（以下， MR），Kはさまざまな組み合わせが考えられることか ら，組み合わせを変化させそれぞれ予測を行い，誤差が 少なくなるような組み合わせを選定する.今回は，Mは それぞれ2～5，Kは1～20の範囲で選定を行う.

また, PalangkaRaya水位と雨量の数值にはおおよそ 100倍の差が存在する. このためユークリッド距離の算 出時に，水位によるものと雨量によるものが等価でなく なるといった問題が生じる. よって, 雨量データを 100 表-2＼cjkstart組み合わせパターン表

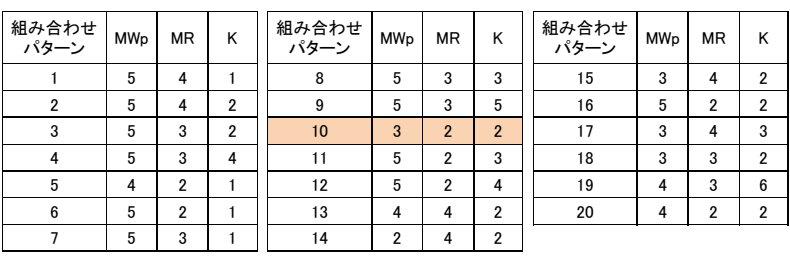

で除し，水位データと雨量データのオーダーを揃えると いう処理を行った.

誤差評価には，次式に示す平均二乗誤差平方根（以下 RMSE）を用い，RMSEが小さいものを誤差が小さいと みなす。また，全期間のRMSEとは別に，本研究では乾 季に着目した誤差として，7～9月の3ケ月間を抽出した RMSE（以下，Dry-RMSE）についても合わせて用いる.

$$
\text { RMSE }=\sqrt{\frac{\sum\left(H_{c a l}-H_{o b s}\right)^{2}}{N}}
$$

ここで， $H_{c a l}$ は予測水位 $(\mathrm{m}), H_{o b s}$ は観測水位 $(\mathrm{m}), N$ は データ数である.

まず，2002～2003年の1ヶ月先予測において構成因子， M，Kの全ての組み合わせでDry-RMSE，RMSEを求めた。 構成因子は雨量を加えたものとし，Dry-RMSEが小さい 順にM，Kの組み合わせパターンを並べたときのDryRMSEとRMSEの推移を図-6に示す。この際，構成因子 がPalangkaRaya水位のみの場合も図-6と同様に作成した が，Dry-RMSE，RMSEの值が図-6よりも大きな值で推 移していたため，雨量を加えた場合を構成因子として選 定した。また，図一6の組み合わせパターンに着目すると， 組み合わせパターン10のときにDry-RMSEとRMSEが総 合的に小さくなることから，組み合わせパターン10であ るMWp=3，MR=2，K=2を選定した．（表-2参照）

\section{（4）水位予測結果}

水位予測を実施し結果の検証を行う。本研究では以下 の6パターンの予測を試み，予測結果を表-3に示した.

(1) 前節において選定された構成因子， M，Kを用いて 2002年〜2003年の1月先の予測を行う.

(2) 前節において選定された構成因子， M，Kの汎用性 を確認するために，選定に使用した期間とは別の 期間である2004年〜2005年の予測を試みる.

(3) 予測パターン(1)と予測パターン(2)を合わせて2002 年〜2005年の予測とし，実測水位との比較を行う。

(4) 下流の観測所であるMantaren観測所の水位を構成因 子に追加することで，精度の向上を試みる.

(5)リードタイムを2ヶ月とし，2ヶ月先予測はどの程 度行えるのかを検証する。

６）実測雨量ではなくGPCPグリッドデータの雨量（以 下，GPCP雨量）にした場合の予測精度を検証する。

表-3について，予測パターン(1)と予測パターン(2)の Dry-RMSEとRMSEをそれぞれ比較するとほぼ同じ精度 


\section{表-3 予測結果表}

\begin{tabular}{|c|c|c|c|c|c|c|c|c|c|}
\hline 予測パターン & データベース期間 & 予測期間 & 使用した雨量 & リードタイム & 構成因子 & 連続データ数 & 抽出水位数 & Dry-RMSE(m) & $\operatorname{RMSE}(\mathrm{m})$ \\
\hline (1) & 1980年～2000年 & 2002年～2003年 & 実測雨量 & 1ヶ月 & PalangkaRaya水位, 雨量 & $\mathrm{MWp}=3, \mathrm{MR}=2$ & 2 & 0.809 & 0.772 \\
\hline (2) & 1980年 2000年 & 2004年 2005年 & 実測雨量 & 1ヶ月 & PalangkaRaya水位, 雨量 & $\mathrm{MWp}=3, \mathrm{MR}=2$ & 2 & 0.847 & 0.712 \\
\hline (3) & 1980年 2000年 & 2002年～2005年 & 実測雨量 & 1ヶ月 & PalangkaRaya水位, 雨量 & $M W p=3, M R=2$ & 2 & 0.828 & 0.740 \\
\hline (4) & 1996年～2000年 & 2002年～2005年 & 実測雨量 & 1ヶ月 & PalangkaRaya水位, 雨量 & $\mathrm{MWp}=2, \mathrm{MR}=2, \mathrm{MWm}=2$ & 2 & 0.424 & 1.054 \\
\hline (5) & 1980年～2000年 & 2002年 2005年 & 実測雨量 & 2ヶ月 & PalangkaRaya水位, 雨量 & $\mathrm{MWp}=4, \mathrm{MR}=2$ & 2 & 1.425 & 1.154 \\
\hline (6) & 1980年～2000年 & 2002年～2005年 & GPCP雨量 & 1ヶ月 & PalangkaRaya水位, 雨量 & $M W p=3, M R=4$ & 5 & 1.022 & 0.857 \\
\hline
\end{tabular}

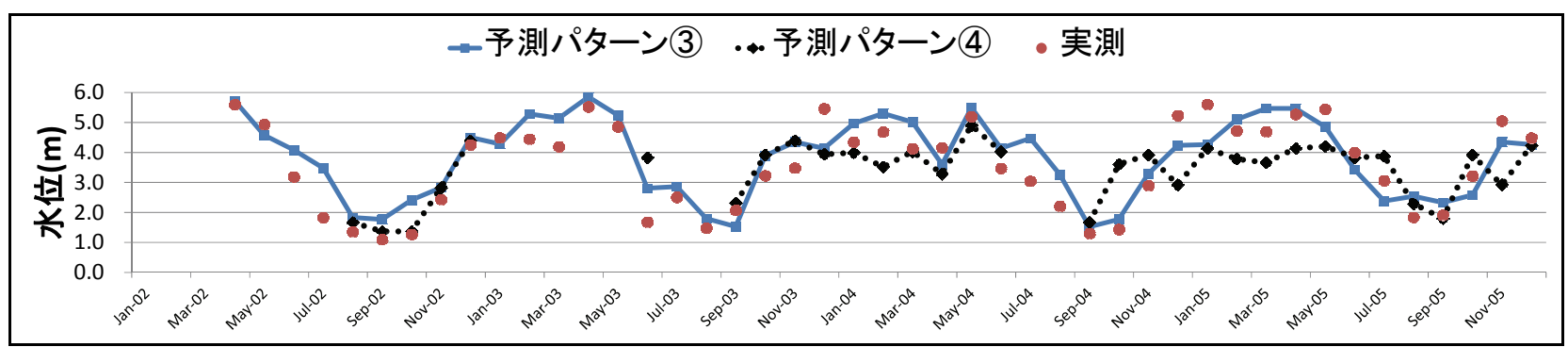

図-7 1ヶ月先の予測結果

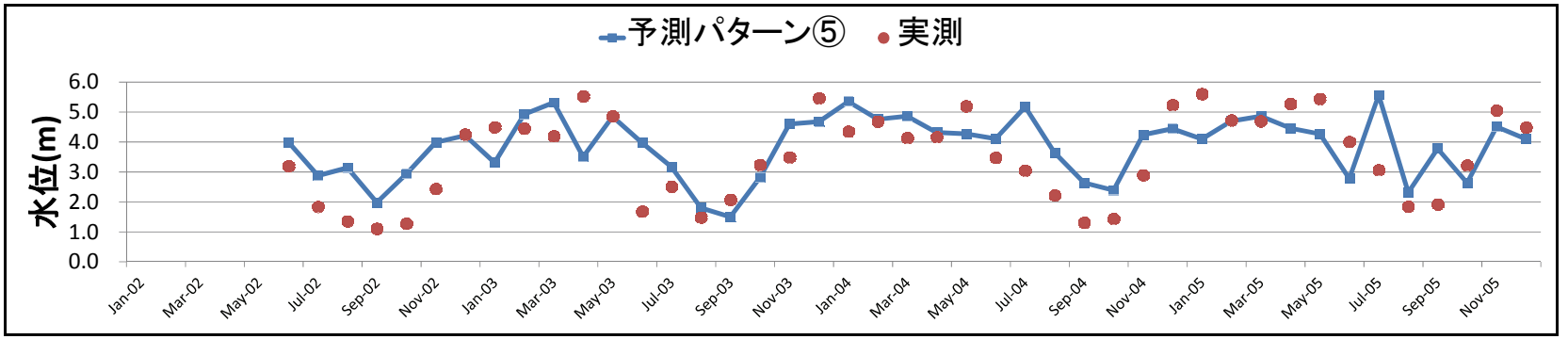

図-8２ヶ月先の予測結果

で予測が行われていることがわかり，選定された構成因 子，M，Kが汎用性を持っていることが検証された。

次に，予測パターン(1)と予測パターン(2)を合わせ， 2002年〜2005年の予測としたものが予測パターン(3)であ り，予測水位と実測水位の比較を図-7に示した。ここで 予測パターン(3について，02年の1月～3月は水位が記さ れていないが，これは01年の水位が欠測であったために 予測が行えなかった期間である。図-7の予測パターン(3) と実測に着目すると，実測水位の変動に沿って予測水位 も同様の変動を示し，水位の傾向を十分に再現出来てい ることがわかる。これは，1ケ月という予測期間を考え ると十分に評価できるものである。しかしながら，02年 の低水時が過大に予測されており，03年の低水時は水 位低下が遅れており精度の改善が求められる期間が存在 することから低水時予測の精度をさらに向上させるため に予測パターン (4)として，下流のMantaren観測所におい て観測された水位を構成因子に加えることを考えた. Kahayan川は内陸部まで潮汐の影響を大きく受けること が知られているが，潮位の観測は十分に行われていない そこで，Mantaren観測所（図-1参照）で観測された水 位を構成因子に組み込むことで，間接的に潮位の影響を 含めた予測が行われるのではないかと考えた.

Mantaren水位を構成因子に含めたときのMWp，MR， Mantaren水位のM（以下，MWm），Kの組み合わせを 図-6と同様のグラフを作成し，選定した．MWp，MR， MWm，Kの組み合わせは表-3の通りであり，予測水位 を図-7に示した．なお，図-7の予測パターン(4)では水位
が記されていない期間が大幅に増加しているが，これは Mantaren水位が久測であったためのものである.

図-7の予測パターン(4)と実測に着目すると，02年の低 水位時の予測精度が格段に向上しており，05年の低水位 時の予測精度も改善されていることから，低水位時の予 測精度については大きく改善される可能性が示されたと いえる. しかし，表-3のRMSEの值を見るとわかる通り 全体的な精度としては良いとは言えず，図-7より高水時 は悪化していることがわかる．このことから，低水時予 測と高水時予測それぞれにおいて使い分けが必要である といえる. RMSEが大きな值となった理由を考察すると， Mantaren観測所で水位が観測されたのは1996年からであ るため，データベース期間が激減する（表-3，データ ベース期間参照）ことが大きな理由として考えられる.

さらに，予測パターン(5)として，2ケ月先の予測がど の程度行えるのかを検証した。構成因子をPalangkaRaya 水位と雨量とし，予測パターン(1)と同様に2002年～2003 年の予測において構成因子の検討を行い，2002年～2005 年の予測を図-8に示した. 図-8に着目すると，水位の傾 向を再現出来ている期間とそうでない期間が存在し，予 測精度が不安定であることがわかる，しかしながら，実 測水位と全く異なっている訳ではなく，今後精度を向上 させていく上での足掛かりとなっている.

最後に予測パターン6とし，GPCPより $2.5^{\circ}$ グリッド データ ${ }^{10)}$ を使用し，実測雨量を用いた場合に対しどのよ うな精度の違いが生じるかを検証した。 なお，使用した GPCP雨量についてはPalangkaRaya観測所に最も近いグ 


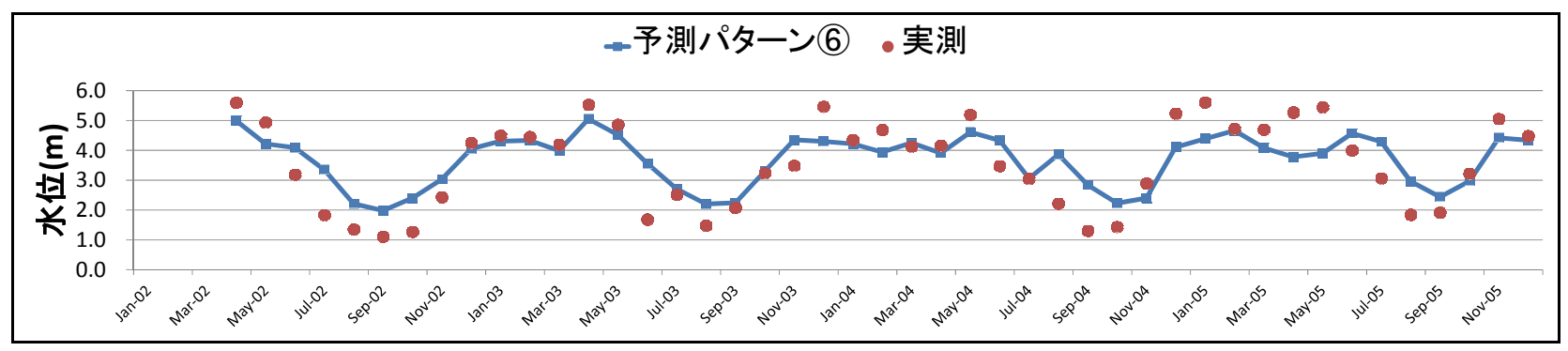

図-9ＧPCP雨量を用いた1ヶ月先の予測結果

リッドを抽出し，その雨量データを使用している.

PalangkaRaya水位とGPCP雨量を構成因子として考え， 予測パターン（1)と同様に最適なM，Kを選定し，2002年 〜2005年の予測を行い図-9に示した，図-9を見ると，予 測水位が実測水位に比べて変動幅が小さく，低水位の定 量的な再現には至っていないことが見受けられるが水位 の上昇や低下といった傾向は十分に再現できていること がわかる.このことから，実測雨量が欠測などにより使 用できない状況であってもGPCP雨量を用いることで最 低限の予測が可能であると判断できる.

\section{5. まとめ}

本研究で得られた知見を下記に示す.

1) El Niño event・IOD といった気象現象は Kahayan 川 の流域雨量と密接に関係しており，特に El Niño event は Kahayan 川の水位低下の大きな要因となっ ていることが示された。

2) 適切な構成因子, $\mathrm{M}, \mathrm{K}$ を選定した結果，1 ケ月先 の予測については十分に傾向をとらえた予測が可能 であり，さらに構成因子選定に用いた期間と予測期 間を変化させて予測を行うことにより，汎用性を確 認できた. また，予測地点よりも下流の水位を構成 因子に組み込むことで，低水位予測の精度が向上す る可能性が示された.

3) GPCP 雨量を用いた予測を試みた結果, 実測雨量が 使用できない状況であっても，GPCP 雨量を用いて 最低限の予測は可能であることが示された.

雨量を構成因子に組み込んだ予測により十分に評価で きる結果が得られ，その雨量はEl Niño eventなどの気象 現象に左右されることが示された. 今後, さらなる予測 精度向上を図ることで地下水をコントロールするための, 実用的手法の提案につなげていきたい.

謝辞 : 本研究を遂行するにあたり Kahayan川関連データ を提供して頂き，また現地調査で大変お世話になりまし たJST/JCAプロジェクト：インドネシアの泥炭・森林に おける火災と炭素管理，地域管理グループのNPO法人北 海道水文気候研究所の高橋英紀先生, 株式会社リブテッ クの板倉忠興先生, 北見工業大学の渡邊康玄先生, 日本
工営株式会社の杉本光様, PalangkaRaya大学のAswin Usup先生に対し，ここに記して深謝致します.

\section{参考文献}

1) JST/JCA プロジェクト HOME http://www.census.hokudai.ac.jp/html/JSTJCA/jp/index.html

2) 佐藤空, 井上京, 石倉究, 波多野隆介, 平野高司, 高橋 英紀, Untung DARUNG, Adi JAYA, Suwido LIMIN : イ ンドネシア中部カリマンタン州の熱帯泥炭地における地 下水位変動と泥炭火災, 日本湿地学会第 2 回学術報告会, 2010.

3) 早坂洋史, エリアント インドラ プートラ, アスウィ ン ウッスプ, ユリアンティ ニナ : インドネシア, カ リマンタン島での最近の泥炭火災傾向,

Japan Geoscience Union Meeting 2010.

4) 三宅龍平, 井上京, アディ・ジャヤ, ウントゥン・ダル ン: カリマンタン熱帯泥炭地における蒸発散量と流出量 の推定, 農業土木学会全国大会講演要旨集, pp.698699,2005 .

5) 国際機関日本アセアンセンターHP: http://www.asean.or.jp/ja

6) 気象庁 HP: http://www.jma.go.jp/jma/index.html

7) 山形俊男 : インド洋のダイポールモード現象と日本の夏, 海洋政策研究財団，第 17 回フォーラム, 2004

8）社団法人電力土木技術協会 HP: http://www.jepoc.or.jp/

9) 海洋研究開発機構, 地球環境フロンティア研究センター HP: http://www.jamstec.go.jp/frcgc/jp/index.html

10) ドイツ気象局 HP: http://www.dwd.de/

11) 満倉真, 貞本均, 中津川誠 : Nearest-Neighbor 法による大 河川の洪水予測について, 河川技術論文集, 第 8 巻, pp.443-448,2002.

12) 満倉真, 貞本均, 中津川誠 : Nearest-Neighbor 法による感 潮河川の水位予測，水文・水資源学会誌，Vol.15,No.4, pp.371-380,2002.

13) 藤原洋一, 田中丸治哉, 畑武志, 多田明夫 : NearestNeighbor 法による実時間流出予測の実用的適用法に関す る研究，水文・水資源学会誌 Vol.16,No.1,pp.33-44,2003.

14) 三野基之, 中津川誠, 板倉忠興, 杉本光 : NearestNeighbor 法を用いたインドネシア Kahayan 川の水位予測, 土木学会北海道支部論文報告集，67 号，B-34,2011.

(2011.9. 30受付) 